\title{
KETIDAKPATUHAN DOKTER SPESIALIS OBSGIN DALAM MELAKSANAKAN CLINICAL PATHWAY
}

\section{Munjari}

Universitas Jenderal Soedirman Purwekorto Jawa Tengah,Indonesia

Email: munjari74@gmail.com

\section{Abstract}

The purpose of this study is to data who obsgin specialists do not comply in clinical pathways in every way sectio caesaria medical education services. Qualitative research type by way of interview indepth how it works. The results of the study idawan each informant already understand the purpose and purpose of clinical pathways but has not been informed with four reasons, namely not in, the request of doctors, management of the word, and the unclear existence of the order. What this does leads to changes in quality and cost and patient safety so that hospital performance is patient.

Keywords: noncompliance; obstetrics and gynecology; clinical pathway

\begin{abstract}
Abstrak
Tujuan penelian ini adalah untuk memperoleh data mengapa dokter spesialis Obsgin tidak patuh dalam menggunakan clinical pathway dalam setiap tindakan pelayanan asuhan medis sectio caesaria. Jenis penelitian kualitatif dengan metode pendekatan kasus indepth interview. Hasil penelitian menemukan setiap informan sudah memahami maksud dan tujuan clinical pathway tetapi belum melaksanakannya dengan empat alasan, yaitu tidak dilibatkan, permintaan pasien, kebijakan manajemen, dan tidak jelas adanya perintah. Ketidakpatuhan ini membawa implikasi terhadap peningkatan mutu dan biaya serta keselamatan pasien sehingga mengancam kelangsungan performa rumah sakit.
\end{abstract}

Kata Kunci: ketidakpatuhan; dokter spesialis obsgin; clinical pathway

\section{Pendahuluan}

Dunia perumahsakitan adalah dunia yang paling dinamis dan sensitif terhadap perubahan. Isu mikro dan makro dalam organisasi rumah sakit tidak saja terkait dalam kontek lokal melainkan sampai pada kontek global. Semakin banyak aktor lintas negara yang terlibat dalam pengelolaan rumah sakit di Indonesia. Saat ini disadari bahwa, perubahan terjadi begitu cepat dalam dunia usaha rumah sakit, kerumitan masalah terus bertambah.

Rumah sakit merupakan institusi pemberi layanan jasa yang memiliki peran penting bagi kehidupan masyarakat. Dewasa ini rumah sakit di seluruh dunia menghadapi suatu fase strategis pembaharuan untuk berubah menjadi suatu organisasi yang fleksibel yang dapat menawarkan layanan dengan kualitas tinggi dan dengan biaya

\begin{tabular}{|c|c|}
\hline $\begin{array}{l}\text { How to cite: } \\
\text { F-ISSN. }\end{array}$ & $\begin{array}{l}\text { Munjari (2021) Ketidakpatuhan Dokter Spesialis Obsgin dalam Melaksanakan Clinical Pathway, } \\
\text { Syntax Idea 3(4). http://dx.doi.org/10.36418/syntax-idea.1141 }\end{array}$ \\
\hline $\begin{array}{l}\text { E-ISSN: } \\
\text { Published by: }\end{array}$ & $\begin{array}{l}\text { 2684-883X } \\
\text { Ridwan Institute }\end{array}$ \\
\hline
\end{tabular}


yang rendah atau terjangkau. Rumah sakit-rumah sakit ini menghadapi suatu tantangan manajerial yang penting untuk mengubah strategi peningkatan pelayanan jangka panjang dengan tetap mempertahankan mutu dan kualitas pada pelayanan saat ini (David, 2010).

Dalam mempertahankan dan meningkatkan mutu dan kualitas pelayanan kesehatan tentu saja diperlukan suatu kemampuan manajerial yang memadai. Sementara proses manajemen sendiri adalah sebuah proses perencanaan, pengorganisasian, pengarahan, dan pengawasan usaha-usaha para anggota organisasi dan menggunakan sumber daya dan sumber daya manusia yang terorganisasi agar dapat mencapai tujuan organisasi yang telah ditetapkan (Stoner \& Freeman, 2006). Untuk menjaga mutu terutama dalam pelayanan kesehatan (quality assurance) memerlukan suatu rangkaian kegiatan pelayanan kesehata $=m n$ berdasarkan standar dan prosedur medis yang semestinya agar mutu pelayanan kesehatan tetap terjaga, ditinjau dari pandangan pemberi pelayanan kesehatan maupun kepuasan pasien (Sutoto, Wibowo, Daniel. B, 2013).

Mutu pelayanan kesehatan dapat ditunjukkan dengan memberikan pelayanan yang memuaskan bagi setiap pemakai jasa dan sesuai dengan standar pelayanan (Azwar, 2006). Upaya peningkatan mutu sebaiknya dilaksanakan secara terpimpin, terarah, terpadu, menyeluruh, dan berkelanjutan (DeSantis et al., 2006). Perbaikan dan peningkatan mutu pelayanan kesehatan dilakukan secara periodik. Untuk dapat memberikan pelayanan berstandar mutu tersebut, setiap rumah sakit berkewajiban untuk mengikuti Akreditasi (Permenkes, 2011).

Akreditasi adalah pengakuan terhadap rumah sakit yang diberikan oleh lembaga independen penyelenggara akreditasi baik akreditasi nasional maupun akreditasi internasional yang ditetapkan oleh Menteri (Permenkes, 2011). Standar akreditasi yang wajib diikuti oleh seluruh rumah sakit di Indonesia adalah Akreditasi Nasional yang dikomandoi oleh Komisi Akreditasi Rumah Sakit (KARS, 2016).

Menurut KARS versi 2012 bahwa rumah sakit yang akan dilakukan penilaian akreditasi harus menerapkan standar pelayanan yang berfokus pada pasien sehingga pengendalian mutu dapat ditingkatkan. Bahkan Peraturan Presiden R.I Nomor 12 tahun 2013 tentang Jaminan Kesehatan Pasal 41 sampai 44 menyatakan bahwa dalam proses pemberian pelayanan harus dilakukan dengan memperhatikan kendali mutu dan kendali biaya.

Salah satu standar pelayanan yang berfokus pada pasien yang dapat mengendalikan mutu, biaya dan mendorong keselamatan pasien adalah penerapan alur pelayanan pasien. Bentuk alur pelayanan pasien yang dapat mengendalikan mutu dan biaya menurut KARS versi 2012 adalah clinical pathway. Clinical Pathway (CP) adalah suatu konsep perencanaan pelayanan terpadu yang merangkum setiap langkah yang diberikan kepada pasien berdasarkan standar pelayanan kedokteran dan asuhan keperawatan yang berbasis bukti dengan hasil yang terukur dan dalam jangka waktu tertentu selama di rumah sakit (Firmanda, 2016). 
Menurut (Moon, Park, Kim, \& Yang, 2003) Clinical pathway adalah standar pengukuran yang telah direncanakan berdasarkan waktu/ jadual terhadap prosedur pelayanan terhadap pasien. Masing-masing tahapan dari pasien masuk sampai pulang telah distandarisasikan. Standarisasi CP menjamin mutu, mengurangi resiko, meningkatkan efisiensi dan mengendalikan biaya (De Bleser et al., 2006). Sedangkan clinical pathway menurut Dep.Kes., 2008 adalah suatu konsep perencanaan terpadu, pelayanan kepada pasien mulai dari masuk sampai keluar rumah sakit berdasarkan standar pelayanan medis, standar asuhan keperawatan, dan standar pelayanan tenaga kesehatan lain yang berdasarkan bukti yang diberikan pada pada pasien. Pengertian keempat definisi CP tersebut dapat diambil kesimpulan bahwa CP adalah salah satu instrumen pemberian pelayanan kepada pasien rawat inap yang terstandarisasi dari pasien masuk sampai pulang yang berfokus pada manajemen pengendali mutu dan biaya.

Penelitian CP sebagai salah satu instrumen yang terstandarisasi yang digunakan dalam manajemen pengendali mutu dan biaya adalah penelitian yang dilakukan oleh (He \& Yang, 2015) tentang evaluasi penerapan CP di rumah sakit umum China diperoleh hasil penelitian sasaran utama untuk menstandarisasi prosedur dengan mengurangi lama rawat inap/ length of stay (LoS) dan mengendalikan biaya belum sepenuhnya tercapai karena pihak manajemen belum memahami bahwa CP merupakan instrumen yang efektif untuk menggerakkan dan mengendalikan biaya guna mendapatkan pendapatan yang signifikan, dokter masih berorienasi pada pendapatan yang diperoleh. Sedangkan penelitian yang dilakukan oleh (Moon et al., 2003) yang melakukan penelitian tentang pengaruh CP dalam tindakan operasi Hernia Inguinalis di rumah sakit Soul menemukan bahwa dari 100 pasien sebagai sampel terdiri dari 60 pasien dijadikan kelompok eksperimen dan 40 pasien sebagai kelompok kontrol. Ditemukan bahwa pasien yang diberlakukan CP lebih efisien biaya, pasien lebih puas, informasi lebih terarah dan leng of stay lebih sedikit dibandigkan dengan pasien hernia yang dijadikan kontrol. Menurut (Resnick, 2014) dalam kajian Harvard Business Review menyatakan bahwa pada pasien rawat inap banyaknya variasi pelayanan sebagai akibat dari tidak adanya standarisasi akan menyebabkan kejadian tidak diharapkan (adverse event) dan lamanya rawat inap.

Clinical Pathway yang merupakan salah satu instrumen yang cukup baik untuk pengendalian mutu dan biaya tersebut pada kenyataannya belum diterapkan secara maksimal di seluruh rumah sakit di Indonesia termasuk di rumah sakit di wilayah Banyumas, Purbalingga, Banjarnegara, Cilacap, Kebumen (Barlingmascakeb). Data menunjukkan bahwa terdapat 53 rumah sakit di Jawa Tengah, 10 diantaranya adalah rumah sakit milik pemerintah, dan 43 lainnya adalah rumah sakit milik swasta. Rumah sakit yang tersedia mulai dari rumah sakit yang belum ditetapkan kelasnya berjumlah 8 rumah sakit, rumah sakit tipe $\mathrm{D}$ terdiri dari 15 rumah sakit, rumah sakit type $\mathrm{C}$ terdiri dari 26 rumah sakit, dan rumah sakit type B terdiri dari 3 rumah sakit, dan satu rumah sakit tingkat III (KeMenKes, 2016). Rumah sakit yang telah terakreditasi KARS versi 2012 di Wilayah Kabupaten Barlingmascakeb adalah Rumah Sakit Emmanunel 
Banjarnegara dengan status Terakreditasi Paripurna, Rumah Sakit Nirmala Purbalingga dengan status Terakreditasi Tingkat Dasar, Rumah Sakit Dadi Keluarga dengan status Terakreditasi Tingkat Dasar, Rumah Sakit Prof. Dr. Margono Soekarjo Purwokerto dengan status Terakreditasi Paripurna, Rumah Sakit Tk. III Wijaya Kusuma Banyumas dengan status Terakreditasi Paripurna, dan Rumah Sakit Umum Daerah Banyumas dengan status Terakreditasi Tingkat Utama (KARS, 2016).

Salah satu Kabupaten di wilayah Barlingmascakeb yang rumah sakitnya belum terakreditasi KARS versi 2012 adalah semua rumah sakit yang berada di Kabupaten Cilacap. Rumah sakit di Kabupaten Cilacap ada 6 rumah sakit, yaitu Rumah Sakit Umum Daerah Cilacap sebagai rumah sakit tipe B, untuk Rumah Sakit C adalah Rumah Sakit Islam Fatimah Cilacap, Untuk Rumah Sakit Tipe D adalah Rumah Sakit Aprilia, Rumah Sakit Santa Maria, Rumah Sakit Afdila dan Rumah Sakit Pertamina. Semua rumah sakit di Kabupaten Cilacap tersebut belum dilakukan akreditasi KARS versi 2012 (Kementerian Kesehatan Republik Indonesia data online, diperoleh 2 Mei 2016).

Data dari Kementerian Kesehatan Republik Indonesia tersebut menunjukkan bahwa mutu pelayanan yang diberikan kepada pasien di semua rumah sakit Kabupaten Cilacap masih dipertanyakan, karena rumah sakit yang baik dan bermutu ditunjukkan jika rumah sakit tersebut telah melaksanakan akreditasi KARS versi 12 dengan lulus paripurna.

\section{Metode Penelitian}

Jenis penelitian ini adalah penelitian kualitatif deskriptif, yaitu berupa penelitian dengan metode atau pendekatan studi kasus (Case Study). Menurut Sutedi A, 2009 bahwa studi kasus termasuk dalam penelitian analisis deskriptif, yaitu penelitian yang dilakukan terfokus pada suatu kasus tertentu untuk diamati dan dianalisis secara cermat sampai tuntas. Kasus yang dimaksud bisa berupa tunggal atau jamak, misalnya berupa individu atau kelompok. Di sini perlu dilakukan analisis secara tajam terhadap berbagai faktor yang terkait dengan kasus tersebut sehingga akhirnya akan diperoleh kesimpulan yang akurat. Penelitian ini memusatkan diri secara intensif pada satu obyek tertentu yang mempelajarinya sebagai suatu kasus, yaitu kasus ketidakpatuhan dokter spesialis obsgin dalam melaksanakan clinical pathway. Data studi kasus dapat diperoleh dari semua pihak yang bersangkutan, dengan kata lain data dalam studi ini dikumpulkan dari berbagai sumber (Nawawi \& Hadari, 2003). Sebagai sebuah studi kasus maka data yang dikumpulkan berasal dari berbagai sumber dan hasil penelitian ini hanya berlaku pada kasus yang diselidiki. Lebih lanjut (Arikunto, 2006) mengemukakan bahwa metode studi kasus sebagai salah satu jenis pendekatan deskriptif, adalah penelitian yang dilakukan secara intensif, terperinci dan mendalam terhadap suatu organisme (individu), lembaga atau gejala tertentu dengan daerah atau subjek yang sempit.

Penelitian case study atau penelitian lapangan (field study) dimaksudkan untuk mempelajari secara intensif tentang latar belakang masalah keadaan dan posisi suatu peristiwa yang sedang berlangsung saat ini, serta interaksi lingkungan unit sosial tertentu yang bersifat apa adanya (given). Subjek penelitian dapat berupa individu, 
kelompok, institusi atau masyarakat. Penelitian case study merupakan studi mendalam mengenai unit sosial tertentu dan hasil penelitian tersebut memberikan gambaran luas serta mendalam mengenai unit sosial tertentu. Subjek yang diteliti relatif terbatas, namun variabel-variabel dan fokus yang diteliti sangat luas dimensinya (Danim, 2004).

Menurut (Bogdan, 1993) studi kasus merupakan pengujian secara rinci terhadap satu latar atau satu orang subjek atau satu tempat penyimpanan dokumen atau satu peristiwa tertentu . (Surachmad, 1995) membatasi pendekatan studi kasus sebagai suatu pendekatan dengan memusatkan perhatian pada suatu kasus secara intensif dan rinci. Sementara (Humphrey \& Yin, 1987) memberikan batasan yang lebih bersifat teknis dengan penekanan pada ciri-cirinya. (Ary, Jacobs, \& Razavieh, 1985) menjelasan bahwa dalam studi kasus hendaknya peneliti berusaha menguji unit atau individu secara mendalarn. Para peneliti berusaha menernukan sernua variabel yang penting.

Berdasarkan batasan tersebut dapat dipahami bahwa batasan studi kasus meliputi: (1) sasaran penelitiannya dapat berupa manusia, peristiwa, latar, dan dokumen; (2) sasaran-sasaran tersebut ditelaah secara mendalam sebagai suatu totalitas sesuai dengan latar atau konteksnya masing-masing dengan maksud untuk memahami berbagai kaitan yang ada di antara variabel-variabelnya. Fenomena yang menjadi kasus dalam penelitian ini adalah ketidakpatuhan dokter spesialis Obsgin dalam melaksanakan clinical pathway di Rumah sakit Islam Fatimah Cilacap.

Penelitian yang dilakukan akan menghasilkan data deskriptif berupa kata-kata tertulis / lisan dari orang-orang atau perilaku yang dapat diamati. Pendekatan diarahkan pada latar dan individu secara holistik. Menurut (Moleong LexyJ, 2011) bahwa tujuan dari penelitian kualitatif adalah ingin menggambarkan realita empirik dibalik fenomena mendalam, rinci, dan tuntas.

Manfaat penelitian kualitatif yang dilakukan sesuai dengan (Moleong LexyJ, 2011), diantaranya adalah untuk mengetahui upaya pemahaman penelitian perilaku dan penelitian motivasional, untuk memahami isu-isu rinci tentang situasi dan kenyataan yang dihadapi seseorang, digunakan untuk menemukan perspektif baru tentang hal-hal yang subdah banyak diketahui, dimanfaatkan untuk menelaah suatu latar belakang misalnya tentang motivasi, peranan, nilai, sikap, persepsi, dan juga digunakan untuk meneliti dari segi proses.

Menentukan lokasi penelitian menyatakan cara terbaik ditempuh dengan jalan mempertimbangkan teori substantif dan menjajaki lapangan untuk mencari kesesuaian dengan kenyataan yang ada di lapangan. Sementara itu keterbatasan geografi dan praktis seperti waktu, biaya, tenaga perlu juga dijadikan pertimbangan dalam penentuan lokasi penelitian ((Moleong LexyJ, 2011).

Tempat penelitian yang akan digunakan adalah di Rumah Sakit Islam Fatimah Cilacap sebagai rumah sakit telah menerapkan clinical paathway sebagai bentuk kebijakan yang harus dilaksanakan oleh dokter spesialis, termasuk didalamnya adalah dokter spesialis Obsgin. Tempat dalam menggali data penelitian diatur secara fleksibel dan menyesuaikan kenyamanan informan dalam mengatur waktunya sehingga 
diharapkan dapat mendorong informan untuk dapat memberikan data seluas-luasnya. Penelitian akan dilaksanakan pada bulan Nopember-Desember tahun 2016.

Dari konsep studi kasus penelitian tersebut menunjukkan bahwa penelitian itu harus memenuhi kaidah ilmiah penelitian yang dapat dipertanggungjawabkan

\section{Hasil dan Pembahasan}

\section{Pelaksanaan Clinical Pathway}

Hasil penelitian melalui wawancara mendalam yang dilakukan kepada kedua informan utama tentang pengetahuan, persepsi dan pemahaman pelaksanaan clinical pathway sectio caesaria sebagai konsep dasar pengetahuan yang harus dimiliki oleh seorang pelaksana clinical pathway sectio caesaria di Rumah Sakit Islam Fatimah Cilacap menunjukkan bahwa pada prinsipnya kedua informan utama sebagai dokter spesialis Obsgin yang harus melaksanakan clinical pathway sectio caesaria mempunyai pengetahuan, pemahaman dan persepsi yang sama dengan konsep teori, tujuan dan implementasi dari clinical pathway sectio caesaria tersebut. Hal ini dapat dibuktikan dengan adanya keterkaitan antara pernyataan kedua informan utama dengan konsep clinical pathway, diantaranya sebagai berikut;

"....clinical pathway merupakan standar baku pelayanan medis yang telah distandarisasi baik obatnya, pemeriksaan penunjangnya, berapa hari rawat inapnya" (IU1)

"alur pelayanan klinis disebut juga clinical pathway tadi adalah algoritma bagaimana merawat pasien dengan jenis penyakit tertentu dengan penatalaksanaan asuhan medis, asuhan keperawatan, asuhan gizi yang sudah terstandarisasi. Kira-kira kaya gitu definisinya pak..?”(IU1)

“...sepengetahuan saya mas, clinical pathway disebut juga alur pelayanan klinis namun lebih populer disebut clinical pathway yang merupakan penatalaksanaan terhadap pasien yang telah distandarisasi baik obat, perawatannya, termasuk jenis operasinya, lama rawat inapnya dan lainnya.." (IU2)

“.....tapi ingat pak, clinical pathway itu hanya diterapkan pada pasien yang mempunyai penyakit yang tanpa komorbid, yaitu tanpa komplikasi lain karena standarisasi mestinya tanpa komplikasi kan..?"(IU1)

Penjelasan kedua informan pada prinsipnya sama dengan apa yang telah disampaikan oleh (Firmanda, 2016) bahwa Clinical Pathway (CP) adalah suatu konsep perencanaan pelayanan terpadu yang merangkum setiap langkah yang diberikan kepada pasien berdasarkan standar pelayanan kedokteran (PNPK/PPK) dan asuhan keperawatan yang berbasis bukti dengan hasil yang terukur dan dalam jangka waktu tertentu selama di rumah sakit.

Namun informan utama kesatu (IU1) yang memahami bahwa clinical pathway adalah algoritma, maka merupakan pemahaman yang perlu diluruskan karena 
clinical pathway tidak sama dengan algoritma. Algoritma merupakan salah satu alat bantu lain dalam melaksanakan panduan praktik klinik sehingga dalam isi dan dan tujuan clinical pathway dan algoritma berbeda. Menurut Buku Pedoman Penyusunan Standar Pelayanan Kedokteran yang diterbitkan oleh (Kemenkes R.I, 2014) menyatakan bahwa standar praktik klinik yang berlaku lokal untuk fasilitas pelayanan kesehatan disebut Panduan Praktik Klinis (PPK) yang dapat disertai dengan alur klinis (clinical pathway), algoritme, protokol, prosedur dan standing orders.

Dalam PPK terdapat hal-hal yang memerlukan rincian langkah demi langkah. Maka sesuai dengan karakteristik permasalahan serta kebutuhan, dapat dibuat clinical pathway (alur klinis), algoritme, protokol, prosedur, maupun standing order dengan masing-masing contoh perbedaan dalam aplikasi penanganan kasus antara clinical pathway (alur klinis), algoritme, protokol, prosedur, maupun standing order sebagai berikut (Kemenkes R.I, 2014).

- Dalam PPK disebutkan bahwa tatalaksana stroke non-hemoragik harus dilakukan secara multidisiplin dan dengan pemeriksaan serta intervensi dari hari ke hari dengan urutan tertentu. Karakteristik penyakit stroke non-hemoragik sesuai untuk dibuat alur klinis (clinical pathway, CP) sehingga perlu dibuat $\mathrm{CP}$ untuk stroke non-hemoragik.

- Dalam PPK disebutkan bahwa pada pasien gagal ginjal kronik perlu dilakukan hemodialisis. Uraian rinci tentang hemodialisis dimuat dalam protokol hemodialisis pada dokumen terpisah.

- Dalam PPK disebutkan bahwa pada anak dengan kejang demam kompleks perlu dilakukan pungsi lumbal. Uraian pelaksanaan pungsi lumbal tidak dimuat dalam PPK melainkan dalam prosedur pungsi lumbal dalam dokumen terpisah.

- Dalam tata laksana kejang demam diperlukan pemberian diazepam rektal dengan dosis tertentu yang harus diberikan oleh perawat bila dokter tidak ada maka diatur dalam standing order.

Penjelasan kedua informan utama tentang tujuan dari clinical pathway yang merupakan salah satu alat untuk meningkatkan mutu, keselamatan pasien dan pengendalian biaya pelayanan juga sama dengan konsep teori dan hasil penelitian yang ada. Bukti kesamaan tersebut terekam dalam wawancara mendalam dengan pernyataan sebagai berikut;

“ sudah jelas pak, tujuannnya untuk meningkatkan mutu dan keselamatan pasien...eii juga dapat digunakan untuk pengendalian biaya lah.. ”(IU1)

“.....yang pasti juga agar asuhan yang diberikan kepada pasien tidak keluar dari standar yang telah ditentukan dalam cp”. (IU1)

“...nggak ada tujuan lain kecuali untuk meningkatan mutu pelayanan dan pasiene slamet dan tentu mengendalikan biaya mas...?” (IU2) 
“....tujuannya agar mutunya bagus, efisien biaya dan penting untuk keselamatan pasien”. (IU2)

Penjelasan kedua informan tersebut sejalan dengan konsep clinical pathway sebagai alat untuk meningkatkan mutu, pengendalian biaya dan keselamatan pasien adalah sebagai berikut;

1. Institute of Medicine of America (1999) menyatakan bahwa pelayanan kepada pasien harus transparan dan sesuai kebutuhan pasien sehingga perlu dibuat standarisasi pelayanan yang melibatkan multidisiplin ilmu dengan tujuan meningkatkan kualitas, efisiensi dan keselamatan pasien. Berdasarkan evident based salah satu metode dimaksud adalah clinical pathway

2. Menurut (KARS, 2016) bahwa rumah sakit yang akan dilakukan penilaian akreditasi harus menerapkan standar pelayanan yang berfokus pada pasien sehingga pengendalian mutu dapat ditingkatkan. Bahkan (Peraturan Presiden R.I Nomor 12, 2013) tentang Jaminan Kesehatan Pasal 41 sampai 44 menyatakan bahwa dalam proses pemberian pelayanan harus dilakukan dengan memperhatikan kendali mutu dan kendali biaya. Salah satu standar pelayanan yang berfokus pada pasien yang dapat mengendalikan mutu, biaya dan mendorong keselamatan pasien adalah penerapan alur pelayanan pasien. Bentuk alur pelayanan pasien yang dapat mengendalikan mutu dan biaya menurut KARS versi 2012 adalah clinical pathway

3. Menurut (Moon et al., 2003) Clinical pathway adalah standar pengukuran yang telah direncanakan berdasarkan waktu/ jadual terhadap prosedur pelayanan terhadap pasien. Masing-masing tahapan dari pasien masuk sampai pulang telah distandarisasikan.

4. Dengan standarisasi CP menjamin mutu, mengurangi resiko, meningkatkan efisiensi dan mengendalikan biaya (De Bleser et al., 2006).

5. (Romeyke \& Stummer, 2012) dalam penelitiannya terhadap pelaksanaan clinical pathway pada pasien yang mengalami gangguan nyeri menyimpulkan dan menyarankan kepada para manajer rumah sakit untuk menggunakan clinical pathway karena clinical pathway merepresentasikan strategi manajemen pengendalian biaya secara terus menerus, mengurangi biaya dan menjamin mutu pelayanan karena hasil peelitian menunjukkan penggunaan clinical pathway lebih efisien dibandingkan tanpa menggunakan clinical pathway $(p<0.001)$

6. Clinical pathway menurut Departemen Kesehatan R.I., 2008 adalah suatu konsep perencanaan terpadu, pelayanan kepada pasien mulai dari masuk sampai keluar rumah sakit berdasarkan standar pelayanan medis, standar asuhan keperawatan, dan standar pelayanan tenaga kesehatan lain yang berdasarkan bukti yang diberikan pada pada pasien. 
Dari penjelasan yang disampaikan oleh kedua informan dan konsep teori serta penelitian tentang clinical pathway pada prinsipnya tidak ada gap atau perbedaan.

\section{Ketidakpatuhan Dokter Spesialis Obsgin}

Hasil penelitian data primer melalui wawancara mendalam maupun data sekunder dari evaluasi pengisian lembar/ form clinical pathway sectio caesaria menunjukkan bahwa ketidakpatuhan kedua informan utama sebagai dokter spesialis Obsgin yang melaksanakan clinical pathway sectio caesaria benarbenar terjadi di Rumah Sakit Islam Fatimah Cilacap. Bukti bahwa kedua informan utama tidak mematuhi dalam melaksanakan clinical pathway ditunjukkan pada tabel 2, sebesar 7,1\% pada bulan November 2016 sedangkan pada bulan Oktober dan Nopember 2016 sebesar 0\%. Ketidakpatuhan kedua informan utama juga diakui oleh kedua informan yang menyatakan dengan sepenuh hati belum melaksanakan clinical pathway sectio caesaria sesuai standar yang ditetapkan. Penjelasan ini terekam dalam interview mendalam sebagai berikut;

“..ya..walaupun saya menyadari juga bahwa saya selama ini belum sepenuhnya melaksanakan cp yang seharusnya saya laksanakan dengan berbagai alasan di atas tadi seperti saya hanya dikasih draf cp suruh ngoreksi saja, saya ngga pernah diundang duduk satu meja bersama profesi kesehatan lain untuk membahas cp, pasien minta obat paten diluar cp, sisi lain juga kadang ada kebijakan manajemen yang melemahkan semangat melaksanakan cp salah satunya menurunkan jasa pasien bpjs tanpa diskusikan dengan kami." (IU1)

“..ya saya sadar betul saya pekerja masih baru lagi yang harus bekerja sebaik-baiknya di rumah sakit ini, tapi kadang sifat manusianya muncul ketika ada satu kondisi yang kurang sreg tadi, ya..jasa dan komunikasi tadi. Saya sampaikan ya jasa bukan segala-galanya yang penting fair dan komunikasikan dengan baiklah..iya kan mas..? (IU2)

"mas saya juga sadarlah saya belum dapat melaksanakan kebijakan terkait clinical pathway sectio caesaria seperti yang saya sampaikan di atas ya ada faktor yang berpengaruh salah satunya adalah walaupun saya tidak dilibatkan dalam penyusunan cp, tapi saya tak pernah diperintah atau diundang atau untuk pengisian penggunaan cp, jadi ya biasa-biasa saja, kedua pasien minta obat paten mas piye..., terus sisi lain ada kebijakan direktur tentang penurunan jasa medis tanpa diskusi dengan kami dokter obsgin iya kan...tiba-tiba..sk penurunan jasa turun...piye re..membuat semangat kerjanya jadi kendor ya kan mas .?"(IU2) 
Tentang belum dilakukan audit medik clinical pathway sectio caesaria menjadi alasan tersendiri menjadi salah satu faktor yang mendukung ketidakpatuhan dokter spesialis Obsgin dengan pernyataan informan utama sebagai berikut; "pak kayaknya belum dilakukan audit medis tentang clinical pathway ya..ya itu penting kan sudah lama dilaksakan cp nya. Karena saya belum pernah dipanggil untuk dimintai pendapat atau diberitahu hasilnya gimana..hasilnya? karena saya belum sepenuhnya melaksanakan cp itu. "(IU1)

"tolong dong komite medik atau bidang pelayanan medik agar lebih greget lagi katanya mau akreditasi kok adem ayem saja.” (IU1)

"mas di rsi ini kok katanya mau akreditasi audit medik belum dilaksnakan ya..? saya tahu dari dokter lain termasuk saya sendiri ngga pernah diundang atas hasil audit cp yang penting untuk akreditasi..?" ya.beneran sih ngga diundang, tapi kan penting diaudit dan dikomunikasikan dengan kami dokter agar ada perbaikan. "(IP2)

Dari pernyataan yang disampaikan oleh kedua informan utama dapat diambil kesimpulan bahwa ada empat faktor yang menyebabkan ketidakpatuhan informan sebagai dokter spesialis Obsgin dalam melaksanakan clinical pathway sectio caesaria di Rumah Sakit Islam Fatimah Cilacap sebagai berikut;

a. Tidak dilibatkan dalam penyusunan maupun audit medik clinical pathway sectio caesaria

Komunikasi merupakan hal yang sangat penting dalam mencapai tujuan organisasi terutama komunikasi karena menurut (Robbin \& Judge, 2015) komunikasi berperan mengendalikan perilaku anggota dalam berbagai cara karena fungsi utamanya adalah perpindahan dan pemahaman arti.

Komunikasi yang baik terhadap dokter spesialis Obsgin di Rumah Sakit Islam Fatimah Cilacap sebaiknya lebih efektif menggunakan komunikasi ke arah bawah karena posisi dokter spesialis Obsgin tersebut di bawah pimpinan manajemen. Menurut (Robbin \& Judge, 2015) komunikasi ke arah bawah adalah komunikasi yang mengalir dari satu tingkat dari sebuah kelompok atau organisasi menuju ke level yang lebih rendah. Para pemimpin dan manajer menggunakannya untuk menugaskan tujuan, memberikan instruksi pekerjaan, menjelaskan kebijakan dan prosedur, menunjukkan permasalahan yang memerlukan perhatian dan menawarkan umpan balik.

Dengan harapan jalinan komunikasi yang baik, keterlibatan dokter spesialis Obsgin baik dalam penyusunan maupun audit medik clinical pathway sectio caesaria dapat memecahkan masalah pelaksanaan clinical pathway sectio caesaria yang diwajibkan akreditasi oleh (KARS, 2016). Komitmen dokter spesialis Obsgin dapat ditingkatkan jika dibangun 
komunikasi yang baik. Hal ini sebagaimana dikatakan oleh informan sebagai berikut;

“ mas kami dokter obsgin sadar betullah harus patuhi kebijakan direktur, kami akan manut siap laksanakan perintah asal komunikasi dan bangun sistem yang baik, jangan reaktif tiba-tiba ada kebijakan kaya gitu."(IU2)

b. Pasien minta obat paten diluar clinical pathway sectio caesaria

Informan utama sebagai dokter spesialis Obsgin yang masih menganggap bahwa obat paten lebih baik atau setidaknya lebih mantap menggunakannya dibandingkan dengan obat generik tanpa alasan yang mendasar merupakan pendapat yang perlu diluruskan karena khasiat obat generik maupun obat paten sama saja kuatnya. Menurut (Wilson, Regal, Papp, \& Kimble, 2009) Obat paten adalah hak perusahaan terhadap nama obat produk baru hasil penelitian produknya original namanya disebut paten. Obat paten rata-rata dari penanaman modal asing (PMA). Contoh obatnya Ponstan, Ventolin, Aspirin, dan lainnya. Setelah masa paten habis (6-8) tahun pabrik farmasi lain boleh memproduksi obat dengan isi zat aktif sama dengan nama berbeda. Obatnya disebut mee to atau branded. Sedangkan obat generik adalah obat yang sesuai dengan yang ditulis dalam INN (International Nonpropietary Name) atau dibuat dengan tidak nama dagang tetapi dengan nama zat aktifnya sehingga obat generik dan obat paten khasiatnya sama saja. Jika dokter spesialis Obsgin cenderung menggunakan obat-obat paten maka akan berpotensi terhadap tidak dilaksanakannya CP dengan konsisten artinya dokter spesialis Obsgin tidak patuh terhadap perintah manajemen.

Patuh menurut (Ali, 1999) adalah suka menurut perintah, taat pada perintah atau aturan. Sedangkan kepatuhan adalah perilaku sesuai aturan dan berdisiplin. Kepatuhan adalah merupakan suatu perubahan perilaku dari perilaku yang tidak mentaati peraturan ke perilaku yang mentaati peraturan menurut (Notoatmodjo, 2003). Sedangkan kepatuhan (De Plaen et al., 1994) adalah tingkat seseorang dalam melaksanakan suatu aturan dan perilaku yang disarankan.

Informan utama mengatakan tidak mempunyai waktu untuk menjelaskan tentang khasiat obat generik yang khasiatnya sama dengan obat paten kepada pasien. Kondisi ini akan menyebabkan kecenderungan penggunaan obat paten meningkat tidak sesuai CP sehingga pengendalian biaya obat sulit dilakukan karena dokter spesialis Obsgin hanya menuruti apa yang diminta pasien. Pengendalian biaya melalui obat sangat penting karena menurut (Kementerian Kesehatan Republik Indonesia, 2011) secara nasional biaya obat mendominasi sebesar 40\%-50\% dari jumlah operasional pelayanan kesehatan. 
Dokter berkewajiban melaksanakan kendali mutu dan kendali biaya sebagaimana diamanahkan dalam Undang-undang Nomor 29 tahun 2004 tentang Praktik Kedokteran pasal 49 ayat 1 dan 2 sebagai berikut;

"setiap dokter atau dokter gigi dalam melaksanakan praktik kedokteran atau kedokteran gigi wajib menyelenggarakan kendali mutu dan kendali biaya."(1)

Dalam rangka pelaksanaan kegiatan sebagaimana dimaksud pada ayat (1) dapat diselenggarakan audit medis.(2)

c. Kebijakan manajemen tentang jasa melemahkan semangat dalam melaksanakan clinical pathway sectio caesaria

Dari penjelasan yang disampaikan kedua informan sangat jelas bahwa ketika manajemen membuat sebuah kebijakan apalagi kebijakan tentang penurunan jasa medis dokter spesialis termasuk dokter spesialis Obsgin maka akan mempengaruhi semangat kerja dalam melaksanakan tugas manajemen termasuk dalam melaksanakan clinical pathway sectio caesaria. Dalam kasus ini sebaiknya pimpinan manajemen menjelaskan kepada dokter spesialis Obsgin alasan mengapa setiap keputusan yang diambil terutama keputusan yang sensitif seperti menaikkan atau menurunkan jasa disampaikan dengan komunikatif bahkan bisa berulang beberapa kali.

Alasan mengapa pengambilan keputusan oleh manajemen harus disampaikan dan bahkan berulang kepada dokter spesialis Obsgin karena dapat memberikan komitmen yang tinggi terhadap tugas pokok dan fungsi yang menjadi tanggung jawabnya. Sebagaimana hasil riset yang dilakukan oleh (Dvorak, Haberer, Sitzer, \& Foerch, 2009) menemukan bahwa para pekerja dua kali cenderung berkomitmen dengan perubahan ketika alasanalasan yang melatarbelakangi mereka dijelaskan seluruhnya. Menurut (Leonardo, 2015) bahwa komunikasi manajer ke bawah harus diulang beberapa kali dan melalui berbagai jenis media berbeda agar menjadi sangat efektif.

Komitmen melaksanakan tugas pokok dan fungsi dokter spesialis Obsgin untuk melaksanakan clinical pathway sectio caesaria akan terwujud jika komunikasi dilakukan secara seimbang terhadap setiap keputusan yang diambil oleh manajemen sebagaimana terekam dalam wawancara mendalam terhadap kedua informan sebagai berikut;

“ mas kami dokter obsgin sadar betullah harus patuhi kebijakan direktur, kami akan manut siap laksanakan perintah asal komunikasi dan bangun sistem yang baik, jangan reaktif tiba-tiba ada kebijakan kaya gitu." (IU2) 
"pak kayaknya belum dilakukan audit medis tentang clinical pathway ya..ya itu penting kan sudah lama dilaksakan cp nya. Karena saya belum pernah dipanggil untuk dimintai pendapat atau diberitahu hasilnya gimana..hasilnya? karena saya belum sepenuhnya melaksanakan cp itu. "(IU1)

d. Tidak diperintah agar menggunakan clinical pathway sectio caesaria dengan baik

Komunikasi menduduki peran yang penting dalam organisasi karena komunikasi berperan mengedalikan perilaku anggota dalam berbagai cara karena fungsi utamanya adalah perpindahan dan pemahaman arti (Robbins S.P., Judge T.A., 2015).

Informan yang memberi penjelasan bahwa tidak diperintah oleh pimpinan manajemen untuk melaksanakan clinical pathway sectio caesaria merupakan hambatan dalam komunikasi yang kurang efektif dari pimpinan ke bawahan, dari level manajemen ke pelaksana. Kondisi ini dibuktikan dengan penjelasan informan pendukung kesatu (IP1) sebagai Ketua Komite Medik bahwa kesibukan dokter spesialis Obsgin maka penyusunan CP hanya mengoreksi draf saja dan memberlakukannya dengan perintah lisan saja. Berikut penjelasannya;

“...memang betul pak dpjp (dokter spesialis Obstetri) hanya diberi draf cp sectio caesaria yang dibuatkan oleh dokter umum yang menjadianggota komite medik, begitu juga dengan dpjp yang lain suruh ngoreksi aja karena kalau dikumpulkan ngga ada waktunya. Beliau-beliau kan sibuk jadi ya di buatkan draf suruh ngoreksi, setelah koreksi kami berlakukan cp itu dengan memintanya secara lisan memang ngga pakai surat resmi...wong dokter dah tahu pentingnya cp itu”(IP1)

Terjadi dua persepsi yang berbeda dalam kasus tersebut diatas, dimana informan menganggap tidak dilibatkan kalau hanya sekedar mengoreksi draf dan merasa tidak diperintah kalau perintahnya hanya lisan, sementara pihak pimpinan manajemen (ketua Komite Medik) menganggap informan sudah dilibatkan walaupun hanya sekedar mengoreksi draf dan sudah memerintahkan untuk melaksanakan CP sectio caesaria secara lisan. Maka perlu ada sistem komunikasi efektif yang dibangun antara pimpinan dan pelaksana sehingga akan terjadi kesamaan tujuan dan pemahaman sehingga terjadi saling memberikan kepercayaaan walaupun hanya perintah lisan atau mengoreksi draf saja. Kepercayaan perlu dibangun diatas komunikasi yang efektif karena kepercayaan akan membawa nilainilai baru yang baik sebagaimana disampaikan oleh (Sumohadiwidjojo, 1990) mengatakan bahwa dalam sebuah organisasi nilai-nilai yang dianut 
merupakan konsep dasar dan kepercayaan yang mendasari organisasi mencapai kesuksesan, maka sistem nilai tersebut harus disampaikan secara terbuka kepada seluruh sumber daya manusia dalam organisasi untuk mendorong karyawan membentuk sikap dan perilaku yang sesuai untuk meraih prestasi dan hasil kinerja seperti yang ditargetkan.

Kepercayaan adalah pernyataan psikologis yang terjadi ketika anda menyetujui ketika anda sendiri menjadi rentan terhadap orang lain karena anda memiliki ekspektasi positif mengenai bagaimana hal-hal akan berubah (Menon G, P. Raghubir, 2005). Kepercayaan merupakan atribut utama terkait dengan kepemimpinan; melanggarnya dapat memiliki efek beragam yang serius terhadap kinerja kelompok (Cuenda \& Rousseau, 2007).

Keempat faktor yang menyebabkan dokter spesialis Obsgin tidak patuh terhadap pelaksanaan clinical pathway sectio caesaria perlu menjadi perhatian khusus pimpinan manajemen dalam hal ini Direktur Rumah Sakit Islam Fatimah Cilacap melalui strategi baru. Setidaknya perlu dibangun dua strategi baru, yaitu

1. Strategi membangun komunikasi yang efektif yaitu komunikasi ke arah bawah adalah komunikasi yang mengalir dari satu tingkat dari sebuah kelompok atau organisasi menuju ke level yang lebih rendah. Para pemimpin dan manajer menggunakannya untuk menugaskan tujuan, memberikan instruksi pekerjaan, menjelaskan kebijakan dan prosedur, menunjukkan permasalahan yang memerlukan perhatian dan menawarkan umpan balik (Robbins S.P., Judge T.A., 2015). Komunikasi yang disampaikan lebih dari satu kali atau berulang agar lebih efektif sebagaimana disampaikan oleh (Leonardo, 2015) bahwa komunikasi manajer ke bawah harus diulang beberapa kali dan melalui berbagai jenis media berbeda agar menjadi sangat efektif. Dengan membangun strategi komunikasi yang efektif diharapkan akan membuat dokter spesialis Obsgin patuh terhadap perintah pimpinan manajemen. Fungsi kepemimpinan dimana manajemen harus mengarahkan dan mengoordinasikan orang-orang dalam organisasi. Manajemen terlibat untuk memotivasi pekerja, mengarahkan aktifitas pekerja, memilih saluran komunikasi yang efektif, dan juga menyelesaikan konflik di antara anggota. Sedangkan dalam fungsi pengendalian, manajemen mengawasi kinerja organisasi dan membandingkan dengan tujuan-tujuan yang ditetapkan sebelumnya. Manajemen melakukan pengawasan, perbandingan, dan koreksi (Robbins S.P., Judge T.A., 2015).

2. Strategi kepemimpinan transformasional, yaitu kepemimpinan transformasional adalah gaya kepemimpinan yang menitikberatkan pada para pemimpin yang berusaha menginspirasi para pengikutnya untuk melampaui kepentingan diri mereka sendiri dan yang berkemampuan 
untuk memiliki pengaruh secara mendalam dan luar biasa terhadap para pengikutnya. Jadi menginspirasi para pengikut untuk melampaui kepentingan diri mereka sendiri demi kepentingan organisasi dengan mengutamakan keramahan individu, menstimulasi intelektual, memotivasi inspirasional (kreatifitas) dan mewujudkan ide. Keramahan individu, menstimulasi intelektual, memotivasi inspirasional (kreatifitas) dan mewujudkan ide harus dijaga agar tidak menurunkan motivasi pelaksana karena menurut (Sumohadiwidjojo, 1990) mengatakan bahwa ada delapan penyebab kurangnya motivasi karyawan tidak ingin melakukan pekerjaan yang menjadi sasaran kerja atau tanggung jawabnya, yaitu pekerjaan yang monoton, negative thinking, karyawan merasa kurang dihargai, terjadi konflik antar rekan kerja, politik kantor yang kurang sehat, manajemen yang otoriter,kurangnya dukungan atasan, tidak ada program pembinaan. Sehingga seorang pimpinan rumaha sakit harus memahami organisasi yang dipimpinnya sebagaimana yang disampaikan menurut (Subanegara, 2005) menyatakan bahwa seorang direktur rumah sakit adalah bagaimana ia tahu persis mengenai segala hal yang bersangkutan dengan perumahsakitan dan harus tahu persis mengenai kehidupan organisasinya.

\section{Kesimpulan}

Berdasarkan hasil penelitian dan uraian pembahasan maka dapat disimpulkan bahwa: Pertama, dokter spesialis Obsgin sebagai pelaksana clinical pathway sectio caesaria sudah mempunyai pengetahuan, pemahaman dan persepsi yang baik tentang maksud, tujuan, penyusunan dan implementasi clinical pathway sectio caesaria. Apa yang dijelaskan oleh kedua informan utama sebagai pelaksana clinical pathway sectio caesaria tidak ada perbedaan yang prinsip dengan konsep maupun teori tentang clinical pathway.

Kedua, pelaksanaan clinical pathway sectio caesaria oleh kedua informan utama sebagai dokter spesialis Obsgin di Rumah Sakit Islam Fatimah Cilacap belum dilaksanakan dengan optimal sebagaimana yang ditetapkan dalam clinical pathway sectio caesaria. Data menunjukkan rata-rata selama tiga bulan hanya satu tindakan sectio caesaria yang sesuai clinical pathway dari $54(1,8 \%)$ tindakan sectio caesaria yang harus dilakukan sesuai standar yang ditetapkan dalam clinical pathway sectio caesaria.

Ketiga, informan utama akan berkomitmen melaksanakan perintah pimpinan manajemen dengan syarat dibangun komunikasi efektif dan kepemimpinan yang baik sehingga mempunyai satu tujuan yaitu mensukseskan pelaksanaan clinical pathway sectio caesaria dalam menghadapi akreditasi KARS Versi 2012

Keempat, setidaknya terdapat empat faktor penyebab ketidakpatuhan kedua informan utama sebagai dokter spesialis Obsgin di Rumah Sakit Islam Fatimah Cilacap belum melaksanakan clinical pathway sectio caesaria sebagaimana disampaikan oleh 
kedua informan utama tersebut, yaitu tidak dilibatkan dalam penyusunan maupun audit medik clinical pathway sectio caesaria, pasien minta obat paten diluar clinical pathway sectio caesaria, kebijakan manajemen tentang jasa melemahkan semangat dalam melaksanakan clinical pathway sectio caesaria, dan tidak diperintah agar menggunakan clinical pathway sectio caesaria dengan baik

Kelima, strategi yang dapat dipertimbangkan oleh direktur Rumah Sakit Islam Fatimah Cilacap adalah strategi membangun komunikasi efektif dan strategi kepemimpinan transformasional yang memungkinkan seluruh kebijakan manajemen dapat dilaksnakan optimal oleh para pelaksana termasuk oleh kedua informan sebagai dokter spesialis Obsgin pelaksana tugas clinical pathway sectio caesaria.

Kelima simpulan merupakan hasil analisis penelitian, dimana analisis adalah mencari data sedetail-detailnya tentang pelaksanaan clinical pathway sectio caesaria, mengolah data tersebut menjadi informasi untuk dapat disimpulkan dan selanjutnya untuk dapat digunakan dalam pengambilan kebijakan. 


\section{BIBLIOGRAFI}

Ali, Lukman. (1999). Kamus Besar Indonesia. Balai Pustaka, Jakarta.Google Scholar

Arikunto, Suharsimi. (2006). Produser Penelitian. Suatu Pendekatan Praktik, Jakarta: Rineka Cipta.Google Scholar

Ary, D., Jacobs, L., \& Razavieh, A. (1985). Introduction to educational research. New York. Google Scholar

Azwar. (2006). Menjaga Mutu Pelayanan Kesehatan Aplikasi Prinsip Lingkaran Pemecahan Masalah. Jakarta: Pustaka Sinar Harapan. Google Scholar

Bogdan, Robert dan Steven J. Taylor. (1993). Dasar-dasar Penelitian Kualitatif. Surabaya: Usaha Nasional.

Cuenda, Ana, \& Rousseau, Simon. (2007). p38 MAP-kinases pathway regulation, function and role in human diseases. Biochimica et Biophysica Acta (BBA)Molecular Cell Research, 1773(8), 1358-1375. Google Scholar

Danim, Sudarwan. (2004). Motivasi kepemimpinan dan efektivitas kelompok. Jakarta: Rineka Cipta. Google Scholar

David, Fred R. (2010). Manajemen Strategi, Ed ke-10. Jakarta: Salemba Empat. Google Scholar

De Bleser, Leentje, Depreitere, Roeland, Waele, Katrijn D. E., Vanhaecht, Kris, Vlayen, Joan, \& Sermeus, Walter. (2006). Defining pathways. Journal of Nursing Management, 14(7), 553-563. Google Scholar

De Plaen, Etienne, Traversari, Catia, Gaforio, José J., Szikora, Jean Pierre, De Smet, Charles, Brasseur, Francis, van der Bruggen, Pierre, Lethé, Bernard, Lurquin, Christophe, \& Chomez, Patrick. (1994). Structure, chromosomal localization, and expression of 12 genes of the MAGE family. Immunogenetics, 40(5), 360-369. Google Scholar

DeSantis, Todd Z., Hugenholtz, Philip, Larsen, Neils, Rojas, Mark, Brodie, Eoin L., Keller, Keith, Huber, Thomas, Dalevi, Daniel, Hu, Ping, \& Andersen, Gary L. (2006). Greengenes, a chimera-checked 16S rRNA gene database and workbench compatible with ARB. Applied and Environmental Microbiology, 72(7), 50695072. Google Scholar

Dvorak, Florian, Haberer, Isabel, Sitzer, Matthias, \& Foerch, Christian. (2009). Characterisation of the diagnostic window of serum glial fibrillary acidic protein for the differentiation of intracerebral haemorrhage and ischaemic stroke. Cerebrovascular Diseases, 27(1), 37-41. Google Scholar 
Munjari

Firmanda, Dody. (2016). Clinical Pathways Kesehatan Anak. Sari Pediatri, 8(3), 195208. Google Scholar

He, Jingwei Alex, \& Yang, Wei. (2015). Clinical pathways in China-an evaluation. International Journal of Health Care Quality Assurance. Google Scholar

Humphrey, J. D., \& Yin, F. C. P. (1987). On constitutive relations and finite deformations of passive cardiac tissue: I. A pseudostrain-energy function. Google Scholar

KARS. (2016). Daftar Rumah Sakit Terakreditasi Versi 2012. Retrieved from kars.or.id/accreditation,report/report_accredited.php. Diakses tanggal 2 Mei 2016.

KeMenKes, R. I. (2016). Profil kesehatan Indonesia tahun 2015. Jakarta: Kementerian Kesehatan Republik Indonesia. Google Scholar

Kemenkes R.I. (2014). Pedoman Penyusunan Standar Pelayanan Kedokteran.

Kementerian Kesehatan Republik Indonesia. (2011). Undang-undang Republik Indonesia No.24 Tahun 2011 Tentang Badan Penyelenggara Jaminan Sosial.

Leonardo, Edrick. (2015). Pengaruh pemberian kompensasi terhadap kinerja karyawan pada PT. Kopanitia. Agora, 3(2), 28-31. Google Scholar

Menon G, P. Raghubir, dan N. Schwarz. (2005). Behavioral frequency judgments: Accessibility diagnosticity framework. The Journal Of Consumer Research, 22(2), 212-228. Google Scholar

Moleong LexyJ, Prof. Dr. M. (2011). Metodologi Penelitian Kualitatif Edisi Revisi. Bandung: Penerbit PT Remaja Rosdakarya. Google Scholar

Moon, In Sung, Park, Ho Ran, Kim, Nam Cho, \& Yang, Soo. (2003). The effects of the critical pathway for inguinal hernia repair. Yonsei Medical Journal, 44(1), 81-88.

Nawawi, Hadari. (2003). Metode penelitian bidang sosial, Gajah Mada. University Press, Yogyakarta. Google Scholar

Notoatmodjo, Soekidjo. (2003). Pendidikan dan perilaku kesehatan. Jakarta: Rineka Cipta, 16, 15-49. Google Scholar

Peraturan Presiden R.I Nomor 12. (2013). Jaminan Kesehatan Pasal 41 sampai 44.

Permenkes, R. I. (2011). Pedoman Umum Penggunaan Antibiotik. Peraturan Menteri Kesehatan Republik Indonesia Nomor: 2406. MENKES/PER/XII.

Resnick, Leigh A. (2014). Paving Clinical Pathways. A's Healthcare Update. Google Scholar 
Robbin, S. P., \& Judge, T. A. (2015). Perilaku Organisasi (Enam Belas). Salemba Empat. Google Scholar

Robbins S.P., Judge T.A. (2015). Perilaku Organisasi. Edisi 16. Jakarta: Salemba Empat. Google Scholar

Romeyke, Tobias, \& Stummer, Harald. (2012). Clinical pathways as instruments for risk and cost management in hospitals-a discussion paper. Global Journal of Health Science, 4(2), 50. Google Scholar

Stoner, James A. F., \& Freeman, R. E. (2006). Management. Englewood Cliffs, NJ: PrenticeHall. Inc. Google Scholar

Subanegara, Hanna Permana. (2005). RESENSI: Diamond Head Drill \& Kepemimpinan dalam Manajemen Rumah Sakit. Jurnal Manajemen Pelayanan Kesehatan, 8(2005). Google Scholar

Sumohadiwidjojo, Muhammad Subuh. (1990). Autobiography: the history of Bapak RM Muhammad Subuh Sumohadiwidjojo, founder of the Spiritual Association of Susila Budhi Dharma, or Subud. Subud Publications International. Google Scholar

Surachmad, Winarno. (1995). Pengantar Penelitian Ilmiah; Dasar-Dasar Metode dan Teknik. Bandung: Tarsito Rimbuan. Google Scholar

Sutoto, Dr. dr. MKes dan Wibowo, Daniel. B, dr. (2013). Inovasi PERSI dalam Mutu Pelayanan Kesehatan di RS dalam Skema Jaminan Kesehatan Nasional. Jakarta: PERSI. Forum Mutu IHON.

Wilson, Dalziel J., Regal, Cindy A., Papp, Scott B., \& Kimble, H. J. (2009). Cavity optomechanics with stoichiometric SiN films. Physical Review Letters, 103(20), 207204. Google Scholar

\section{Copyright holder :}

Munjari (2021)

First publication right :

Journal Syntax Idea

This article is licensed under:

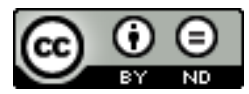

